\title{
BIOGRAFI KH. RUSTAM ARSYAD \\ DI KOTA PALU PROVINSI SULAWESI TENGAH
}

\author{
La Mansi*
}

Balai Peneitian dan Pengembangan Agama Makassar JI. AP.Pettarani No. 72 Makassar Email: lamansilitbang@yahoo.com

\begin{tabular}{|c|c|}
\hline INFO ARTIKEL & ABSTRAK \\
\hline & $\begin{array}{l}\text { Penelitian ini bertujuan untuk menyusun biografi KH. Rustam Arsyad di kota } \\
\text { Palu Provinsi Sulawesi Tengah dengan mengemukakan, kehidupan pribadi, latar } \\
\text { belakang akademik dan pekerjaan yang dilakukan, aktivitas dalam pembinaan } \\
\text { masyarakat, peran yang dimainkan dalam mendidik masyarakat, baik formal } \\
\text { maupun non formal. Jasa-jasa Rustam Arsyad berupa hasil karya yang diwariskan } \\
\text { kepada masyarakat, Sikap dan pandangan keagamaan yang patut menjadi teladan } \\
\text { dan pegangan rnasayarakat, Pandangan dan sikap masyarakat terhadap Rustam } \\
\text { Arsyad. Hasil penelitian ini diharapkan bermanfaat bagi, jajaran Kementerian }\end{array}$ \\
\hline $\begin{array}{r}\text { Kata Kunci: } \\
\text { Biografi KH. } \\
\text { Rustam Arsyad Kota } \\
\text { Palu }\end{array}$ & $\begin{array}{l}\text { Agama dan instansi lain yang berkepentingan sebagai data keagamaan yang dapat } \\
\text { dijadikan dasar pertimbangan dalam pengambilan kebijakan pembangunan di } \\
\text { bidang agama. Para akademisi, pecinta ilmu, serta pihak-pihak lain sebagai } \\
\text { informasi faktual untuk kepentingan pengembangan pengetahuan, Kepustakaan } \\
\text { masyarakat sebagai pengayaan khazanah keagamaan yang dapat berguna sebagai } \\
\text { acuan moral dan intelektual. }\end{array}$ \\
\hline
\end{tabular}

ABSTRACT

This research aims to compile a biography of KH. Rustam Arsyad Hammer in the town of Central Sulawesi province with a fringe, private life, academic background and work performed, the activity in the construction of society, the role played in educating the public, either formal or non formal. Rustam Arsyad merits be works that are passed on to society, attitudes and religious views are worthy of being a role model and the handle rnasayarakat, views and attitudes towards Rustam Arsyad. The results of this research are expected to benefit, the ranks of the Religious Ministry and other concerned agencies as religious data can be relied upon in making development policy considerations in the field of religion. Academics, lovers of science, as well as other parties as factual information for the benefit of the development of knowledge, the library community as a corpus of religious enrichment that can be useful as a reference to the moral and intellectual.

\section{PENDAHULUAN}

Ulama adalah salah salah seorang tokoh yang menjadi sentral dalam pembinaan keagamaan, bimbingan moral, spiritual umat, agar umat tetap berada dalam agama Islam yang menjadi rahmat bagi seluruh alam (rahmatan lil alamin). Peran Ulamaadalah multi dimensi dalam pembinaan umat setiap generasi pada masanya, bahkan setiap negara selalu ada muncul ulama. Begitu urgennya peran ulama, sehingga banyak tempat sosiohistoris masyarakat sering disandarkan pada ulama. Begitu penting posisi ulama, sehingga masyarakat memberikan gelar kehormatan yang bersifat kultural"Kiyai,
Anre Guru dan Tuan Guru". (Santing, Waspada. 2010: ix-xvii).

Ulama adalah sebuah gelar kehormatan, memiliki peran multi dimensi dalam pembinaan umat, karena ia cerdik cendekia, mereka bersentuhan dengan perkembangan peradaban umat Islan. Sebagai aktor utama dalam sejarah kehidupan umat, hadir dalam kehidupan umat, mereka melakonkan skanario wahyu Allah wat, Ulama sebagai mata rantai dan ahli waris nabi,menghabiskan sebahagian usianya belajar agar mempu mendalami syariat sebagaiwaratsatulanbiya' merupakanelit 
agama yang mendapatpengakuan dariumatnyakarenakeluasanilmuagamanya, kedalamanpemahaman agama, ketinggian moral dan akhlaknya. Dia tampilsebagaipemimpinmenjadi contoh anutan, terutama darisegikeikhlasan, istiqamah, dan dedikasinya. Ulama adalah tokoh yang mempersentasikan keutamaan agama Islam, membenarkan dakwah Nabi Saw, Imam yang mulia penuh berkah yang abadi, terdidik dengan ajaran Islam, terbina dengan Islam, dengan rahmat Allah menjayakan syariatnya. (Farid Ahmad, Syaikh. 2012: xvii). Ia kaya dengan khazanah keagamaan, budaya sosial, sebagai patron moral dan etika dalam kehidupan dan menjadi salah satu bentuk pendidikan masyarakat. (Jurnal Al-Qalam Jurnal volume 19 Nomor 1 Juni 2013: 418).

Penelitian ini merekomendasikan Biografi ulama yang sudah meninggaluntuk membangkitkan semangat,pemikiran dan pandanganmereka untuk buah penahdengan dasar pertimbangan itu, Bidang Lektur dan Khazanah Keagamaan Balai Litbang Agama Makassar tahun 2015 merasa perlu melanjutkan penelitian tentang biografi ulama untuk lebih memperkaya khazanah keagamaan sebagai bagian dari pembinaan kehidupan masyarakat beragama. Penelitian ini bertujuan untuk menyusun biografi KH. Rustam Arsyad di kota Palu Provinsi Sulawesi Tengah dengan mengemukakan, kehidupan pribadi, latar belakang akademik, pekerjaan yang telah dilakukan, aktivitas dalam pembinaan kehidupan masyarakat, peran yang dimainkan dalam mendidik masyarakat, baik formal maupun non formal, Jasabeliau berupa hasil karya yang diwariskan kepada masyarakatnya, sikap dan pandangan keagamaan yang patut menjadi teladan dan pegangan rnasayarakat.

Hasil penelitian ini diharapkan bermanfaat bagi jajaran Kementerian Agama dan instansi lainnya yang berkepentingan sebagai data keagamaan yang dapat dijadikan dasar pertimbangan dalam pengambilan kebijakan pembangunan di bidang agama, paraakademisi, pecintailmu, sertapihak lain sebagai informasi faktual untuk kepentingan pengembangan pengetahuan dan kepustakaan masyarakat sebagai pengayaan khazanah keagamaan yang dapat berguna sebagai acuan moral dan intelektual.

Majelis Ulama Sulawesi Selatan meengimbau penulisan Biografi Ulama dengan judul Biografi Ulama. Dalam penulisan biografi ini, dilibatkan beberapa penulis yang berhasil mengungkap 14 biografi ulama, bahkan sudah ada di tingkat nasional, seperti AG. H. Muhammad As'ad dan AG. H. Ambo Dalle, yang keduanya sudah tercanturn dalam buku Ensikiopedi Ulama Nusantara, seperti telah dikemukakan. Abd. Kadir Ahmad dalam disentasinya yang kemudian dipublikasikan denganjudul Ulama Bugis menyoroti ulama sebagai figur penting dalam masyarakat. (Abd. Kadir Ahmad. 2009).

AGH Daud Ismail seorang ulama dari Soppeng dikemukakandalam Buah Pena Sang Ulama bersama ulama lainnya yaitu Annangguru Muhammad Shaleh (Mandar), K.H. Hamzah Manguluang (Wajo), KH. Muhamrnad Abduh Pabbajah (Pare-Pare), Ust. Abdullah Said (Balikpapan) dan KH. Dja'far Sabran (Samarinda). (Muhammad As'ad dkk:2011). Jajat Burhanuddin, dalam tulisan mempublikasi beberapa ulama (perempuan) diantaranya Rahmah el Yunusiah pelopor pendidikan perempuan, Nyai Ahmad Dahlan penggerak perempuan Muhammadiyah, Sholihah A.Wahid Hasyimteladan kaum perempuan Nahdiyin, Prof. Dr. Zakiah Darajat pendidik dan pemikir, Syuryani Tahir perintis pengajian perempuan, Tutty Alawiyah Pengembang masyarakat lewat majelis taklim, Aisyah Aminy aktivis politik di partai Islam, $\mathrm{Hj}$. Hadiya Salim pejuang sosial keagamaan, Rofiqoh Darto Wahab Qariah seniman kasidah, Lutfiah Sungkar mubalig keluarga muslim, Ny. Hj. Chamnah tokoh perempuan tarekat Tjanniyah, $\mathrm{Hj}$. Nonoh Hasanah perintis pesantren putri di Jawa Barat. (Jajat Burhanuddin (ed.): 2002) 
Meskipun berbagai tulisan yang memuat biografi ulama telah dikemukakan, namun jumlah ulama di KTI yang terungkap masih sangat terbatas jumlahnya dan masih banyak ulama lain yang belum mendapat sorotan, karena itu diperlukan penyusunan biografi ulama lebih lanjut untuk menambah jumlah biografi ulama yang terungkap sebagai khazanah keagamaan karena itu penting bagi pembinaan dan pendidikan masyarakat. (Azyurnardi Azra: 2002). Penelitian ini mengacu pada Biografi ulama. Biografi berasal dari bahasa Yunani, bios yang berarti hidup, graphien yang berarti tulis. Dengan demikian biografi dapat diartikan tulisan tentang kehidupan seseorang sebagai sebuahkisah riwayat hidup. Biografi dapat disusun dari beberapa alinea saja (biografi singkat) berupa riwayat dari satu buku. (Taufik Abdullah. 1983:3)

\section{Metode Penelitian}

Penelitian ini merupakan penelitian deskriptif kualitatif yang berusaha menyusun Biografi KH. Rustam Arsyad yang berkaitan dengan kehidupan pribadi, peran dan aktivitasnya, sikap dan pandangan hidupnya, serta karya-karyanya yang diwariskan dalam kehidupan masyarakat. Karena berkaitan dengan biografi, maka penelitan ini termasuk penelitian sejarah yang objek perorangan. Penelitian ini dilaksanakan di Kota Palu Provinsi Sulawesi Tengah dilakukan selama 15 hari oleh La Mansi peneliti Bidang Lektur dan Khazanah Keagamaan Balai Litbang Agama Makassar. Setiap peneliti memilih seorang ulama yang sudah meninggal yang tinggal didaerah itu serta berperan membina masyarakat umat beragama. Penentuan KH. Rustam Arsyad yang dipilih sebagai sasaran penelitian karena popularitas dalam masyarakat, keterlibatannya dalam bidang pendidikan agama baik formal atau non formal, serta ketersediaan data yang dibutuhkan.

Penelitian biografi termasuk penelitian sejarah yang objeknya perorangan, maka penelitian ini memakai pendekatan sejarah. Helius Syamsuddin mengemukakan bahwa ada 6 tahap yang harus ditempuh dalam penelitian sejarah memilih topik penelitian, mencari buktibukti (evidensi) yang relevan dengan topik, membuat catatan temuanlapangan yang penting dan relevan, mengevaluasi secara kritis evidensi yang telah dikumpulkan (kritik sumber), menyusun temuan lapangan dalam suatu pola dengan sistematika tertentu yang telah disiapkan, Menyajikan dan mengkomunikasikan dalam satu laporan hasil penelitian yang menarik'. (Helius Syamsuddin. 2007:89)

Teknik pengumpulan data digunakan metode yang ada kaitan dengan data yang dibutuhkan: a). Wawancara dengan informan yang relevan yang memiliki informasi tentang substansi penelitian. Informan dari keluarga, kerabat ulama bersangkutan, yang dekat dengan tokoh masyarakat; b). Studi pustaka dan dokumen yang terkait dengan penelitian. Dokumen yang perlu perhatian adalah dokumen pribadi sasaran penelitian (ulama yang diteliti); c). Observasi terhadap lingkungan masyarakat sekitar ulama yang diteliti terutama kehidupan keagamaan untuk mendapatkan data penunjang.

Karena penelitian ini adalah penelitian kualitatif maka instrumen penelitian adalah penelitinya sendiri, pengolahan data dilakukan dengan pengumpulan data dalam bentuk kata, gambar dan tidak menekankan pada angka, lebih menekangkan pada proses dari pada produk, lebih mmenekangkkan pada makna data yang teramati. (Sugiyono: 22). Kritik sumber, langsung ke sumber data. Peneliti adalah instrumen kunci baik eksternal maupun internal terhadap data yang terkumpul (evidensi). Data yang terkumpul setelah dilakukan evaluasi yang kritis dengan mengkategorikan berdasarkan jenis tertentu, kemudian disusun dalam suatu pola. Analisis data yang dilakukan sesuai dengan jenis data yaitu deskriptif kualitatif dalam bentuk narasi. Data yang telah dikategorisasi dan disusun dengan sistematika tertentu di interpretasi dan 
dihubungkan satu dengan yang lain yang relavan kemudian dilakukan deskripsi berupa narasi.

\section{TEMUAN DAN PEMBAHASAN}

\section{Kehidupan Sosial Rustan Arsyad sebagai Pendidik dan Pembelajar Unggul.}

Kenyataannya tidakmudah seorang guru mampu menjadikan peserta didik menjadi manusia yangberkualitas dan berakhlak mulia menuju arah kehidupan yang lebih baik. Tentu saja hal itu membutuhkan beberapa syarat yang harus dipenuhi. Sejumlah syarat yang dapat menjawab tantangan dan peluang pembelajaran serta menyusun strategi pembelajaran yang unggul dan profesional. Profesionalisme bukan hanya memproduksi peserta didik menjadi pintar dan memiliki sejumlah skill, tetapi bagaimana mengembangkan potensi yang dimiliki peserta didik menjadi aktual. Di sinilah kepribadian profesional pendidik yang diidam-idamkandan diharapkan kehadirannya.

Menjadi Pendidik yang Unggul, ini menjabarkan bagaimana menciptakan pembelajaran yang produktif, bermakna dan profesional. Suatu usaha memodifikasi proses integrasi dan optimalisasi sistem pendidikan di sekolah, dengan harapan menjadi pedoman yang signifikan bagi proses pembentukan kepribadian peserta didik yang kokoh, intelektual, moral, skill dan spiritual. Tulisan ini mengajak semua pendidik di lingkungan Alkhairaat khususnya, para pendidik pada umumnya agar dapat menjalankan tugas mulai secara efektif dan profesional dalam melaksanakan fungsi mendidik anak bangsa. Masa depan negeri ini tergantung kepada bagaimana guru dapat melahirkan individu yang merdeka, matang, bertanggungjawab dan peka terhadap permasalahan sosial di lingkungan di kemudian hari. Figur sentral dalam dunia pendidikan, pendidik seyogyanya dapat menjadi proses interaksi dalam pendidikan.
Oleh karena pendidik harus memiliki karakteristik kepribadian yang ideal sesuai dengan persyaratan yang bersifat psikologis-pedagogis, relegius-pedagogik dan sosiologis-pedagogis. Rustam Arsyad, adalah sosok yang tidakterbantahkansebagaiPendidik yang sangatunggul. Keunggulannya sebagai pendidik tidak terlepas dari integritas kepribadian, kualifikasi keilmuan, kompetensi, dan profesionalismenya melampaui batas standar kompetensi guru pada umumnya. Rustam Arsyad adalah pendidik yang sangat sukses pada zamannya. la tampil sebagai pendidik yang aktif, kreatif, inovatif, mencerahkan dan menyenangkan.

\section{Rustam Arsyad Pendidik tidak diragukan.}

Beliau memiliki Spirit untuk mendirikan dan mengembangkan Perguruan Alkhairaat tarnpak pada keberaniannya menghadapi berbagai tantangan, baik dari politis, geografls, maupun sosio-kultural.Sejak proses pengembangan Alkhairaat di bawa kepernimpinan Rustam Arsyad semakin produktif Madrasah Alkhairaat menelurkan generasi terdidik, dalam sejarah tidak terlepas dari tantangan politis. Noor Sulaiman mencatat, bahwa dalam rentang waktu 12 Tahun (1930-1942), Rustam Arsyad dengan kegigihan untuk mengembangkan Alkhairaat di seantero wilayah Indonesia dalam rentang waktu kurang lebih 39 Tahun (1930-1969) Rustam Arsyad, berhasil mengembangkan, menyebarluaskan dan mendirikan Alkhairaat di seluruh kawasan Indonesia, terutama di wilayah bagian Timur yang saat ini telah memiliki ribuan madrasah, ratusan pondok pesantren dan panti asuhan serta perguruan tinggi adalah warisanRustam Arsyad untuk dilestarikan dan dikembangkan secara terus menerus dengan meneladani kepribadian, keteguhan, komitmen dan motivasi, Rustam Arsyad mengembangkan Alkhairaat tanpa menuntut imbalan material. Dengan 
semangat jihad pendidikan dan dakwah Rustam Arsyad perlu direvitalisasi seluruh cabang Alkhairaat karena dalam realitas banyak kota, daerah pelosok wilayah telah berdiri bangunan Madrasah yang dikembangkan langsung oleh Rustam.

\section{Rustam Arsyad sebagai Pendidik Berkepribadian Mulia.}

Rustam Arsyad mengemukakan bahwa seorang pendidik bukan hanya mencerminkan suatu profesi, tetapi merupakan representasi dari berbagai kedudukan yang sangat mulia. Karena kemuliaan itu mengangkat derajat seorang pendidik, maka la harus memiliki kepribadian yang beriman dan bertakwa kepada Allah, kepribadian luhur, mulia dan mampu menjadi teladan pada peserta didiknya. Keteladanan yang diberikan oleh pendidik berdampak besar terhadap kepribadian anak didik. Stephen R. Covey Muhammad Syafi'i Antonio mengatakan, karakter seseoranglah yang melakukan komunikasi yang paling fasih, sehingga mampu memberikan pencerahan bagi siapa pun yang mendengarnya. Keberhasilan Rustam Arsyad dalam mendidik peserta didiknya pada masanya, tidak terlepas pada melekatnya kepribadian Rustam Arsyad sebagai contoh dari peneladanan Nabi Muhammad saw. sebagai pendidik dan pembelajar utama dan pertama pada umat Islam.Makadariitu, sekarang saatnya bagi para pendidik dan pembelajaruntukmencontoh dan melakukan minimal mendekaticara yang sama dilakukan oleh Rasulullah saw. Rustam Arsyad mendidik anak didiknya dengan melihat peranan pendidikan sebagai pencerdasan dan pencerahan kehidupan manusia dapat terwujudkan dengan maksimal.

\section{Mengajar sambil Menyemangati}

Pemberian motivasi adalah salah satu teknik yang dapat meningkatkan semangat dan keinginan yang ingin mengetahui sesuatu yang baru. Dorongan dan motivasi dari seorang guru terhadap peserta didik memompa semangat peserta didik untuk memiliki keinginan kuat guna mencari dan menuntut apa yang hendak diketahuinya. Motivasi adalah suatu cara yang mampu meningkatkan gairah belajar dan rasa keingin tahuan yang tinggiserta rasa penasaran untuk mengetahui apa jawaban dan rahasianya. Motivasi baiksekali untuk memancing semangat belajar, meneliti, dan menelaah suatu pelajaran tertentu. Semakin kuat menggunakan ungkapan yang bernada motivasi, semakin kuat pula motivasi untuk belajar.

Rustam Arsyad adalah seorang motivator yang membangun rasa optimisme yang ulung kepada para pesertadidik, bahkan kepada orangyang ada di sekitarnya. Rustam Arsyad memiliki kemampuan menyampaikan tema sedalam samudera dan seluas dunia di dalamwadah kata yang singkat, namun memukau inspiratif, dan menyenangkan. Rustam Arsyad tampil sebagai pendidik yang kaya dengan petuah yang menyejutkan dan menyegarkan serta dapat menghilangkan kepengatan. dia tampil sebagai pendidik yang unggul menyegarkan dan menyenangkan peserta didik. Pendidik yang berdimensi motivating dan funing yang dilakukan oleh Rustam Arsyad pada dasarnya adalah pendidik yang menyenangkan menjadi salah satu pembelajaran PAIKEM dewasa ini. Joyfull learning merupakan suatu proses pendidikan yang di dalamnya terdapat kohesi yang kuat antara guru dengan pesertadidik, tanpa ada perasaan tertekan secara fisik dan psikis serta emosional dalam proses pembelajaran. Dengan kata lain, joyfull learning adalah pola hubungan yang baikantara guru dengan peserta didik dalam proses pembelajaran.

\section{Upacara Sosial Keagamaan}

\section{Masyarakat, dan Keadaan Keulamaan}

Upacara Sosial Keagamaan (Islam) masyarakat kota Palu pada umumnya masih melaksakan kegiatan sosial keagamaan seperti; Maulid, Barzanji, Tahlil dan Talqin (HS Saggaf Al Jufri ketua utama Al 
Khaerat, wcr. Rabu 30 Sep. 2015).Ccorak keagamaan masyarakat kota Palu (mashab Yang Dianut) pada umumnya menganut paham Ahlu Sunnah wal jamaah. Pendidikan Islam Alkhairaat kota Palu kedudukannya sebagai organisasi Sosial, dan kegiatan kerjanya untuk kepentingan umum, tidak berlindung atau berafiliasi dengan organisasi Polilik atau Sosial lainnya di Nusantara ini. Jadi kedudukan Organisasi Alkhairaat bersifat indenpendent. Menelusuri kegiatan Rustam Arsyad dalam menjalankan perintah Allah SWT, beliau mengikuti aliran Ahlu-Sunnah Waljama'ah, yang biasa juga disebut aliran Asy'ariyah. Mazhabnya adalah Syafi'iyah. "Asy'ariyah, adalah tokoh pengemban ajaran Ahlu Sunah waljam'ah adalah Ali bin Ismail bin Ishak bin Salim bin Ismail bin Abdullah bin Musa bin Bilal bin Abi Burdah bin Abi Musa Al-Asy'aiy, berkunyah Abul Hasan Asy'ariyah, dan mempunyai gelar kehormatan sebagai "Nashharuddin" (Pembela Agama) karena aliran yang diembannya sering disebut aliran Asy'ariyah. (Kembay B. Sofyan, 1991: 49).

Syafi'iyah, Imam Syafi'I melakukan Istimbath senantiasa berpegang pada AlQur'an dan As-Sunnah serta Ijma dan AlQias, Mazhab ini dalam menggunakan Hadist dan Qias merupakan pertengahan antara. Mazhab Hanafi dan Mazhab Maliki. Pendirian Sayed Idrus yang diberikan kepada muridnya Rustam Arsyad dalam melaksanakan faham dan Mazhab tersebut dapat dibaca dalam ungkapannya yang berbentuk syairnya diterjemahkan dalam bahasa Indonesia sebagai berikut; Sungguh amaliyah norma hidupkan berdasarkan pola dan jalurmazhabSyafi' ibilaakuwafat, makaakuberwasiatberharap agar sesudah kunanti hendaknyalah kalian menjadikan Syafi'I panutan" Inilah gambaran pendirian dan sikap Sayed Idrus yang diajarkan muridnya Rustan Arsyad tentang Mazhab yang dianutnya, yang berarti pula yang dianut oleh Alkhairaat.

\section{Kehidupan Pribadi dan Keluarga; Riwayat Pendidikan dan Pekerjaan atau profesi.}

Rustam Arsyad lahir di Kota Palu, 23 September 1922 (69).(nama ini sapaan sebagai seorang ulama besar di Sulawesi Tengah). Kai (panggilan dalam lingkungan keluarga Cucu dan cici). Ustadz dan Guru (sapaan dalam lingkungan Madrasayah AlKhaerat dan murid). Dia anak ke 3 dari Arsyad dengan Suriyah. Suriyah dari Desa Durian Kalimantan Selatan, sejak lama berhijrah kePalu. Rustam Arsyadadalah salah satu murid Guru Tuadari Banjar, dia sangat mahir berbahasa Kaili (Palu). Kakeknya adalahAnam bin Bukasan dari Banjarmasin Kalimantan Selatan kawin dengan seseorang, melahirkan Arsyad, kemudian Arsyad besar di kota Palu Sulawesi Tengah, beliau sangat mahir berbahasa Kaili, bahasa Arab dan bahasa Banjar. Di kota Palu ini Arsyad kawin Suriyah juga dari Banjarmasin, dari perkawinan ini melahirkan10 orang anak yaitu :

1. H. Djuhri/Aminah Tayyeb ( Mahmud, Anwar, Hamsah, Ahmad dan Arifin).

2. Masrum / Sabri ( Ridwan, Jum'an, Masrufa, Masraya, Nursilah, Johan, Lamsina dan Arjan).

3. Rustan Arsyad / Rachmah Dg Mennessa ( Subaedah Arsyad, Drs. H. Abdul Basyid Arsyad M. Pd., Abdullah Arsyad, Taufid Arsyad, Muslim Arsyad dan Munifah Arsyad).

4. Hafsah / Ali Thahir ( Amrani, Nursam, Ishak, Burhan dan Ramlah)

5. Hasbulah / Halimah (Nikmah, Muhammad, Nurhayati, Hasan, Husen, Idrul, Latif, Anis, Sofyan, Fauzi danFauziyah).

6. H. Hamlan / Safiah Saman (Suriah, Salman, Muhtar, Muhlis, Maryam dan Irfan).7. Hasnah /Hainmi Tayyeb (Samsiar, Nurdin, Najib, Jamal, Norma, Nuraini, A.Yani, Fajrin, Gastalani, Yusuf danNursada).

8. H. Muhammad / Salmah Busra(Raodah, Zuber, Lukman, Halim, 
Fatimah, Latifah, Erma Susanti, Zenab danFajrah).

9. Hadijah / Hasan SidikMakassar (Fatmawati, Nurjannah,Raodah,Faridah, Padriani, Mursidik, Mardiatan, Naima dan Raehan).

10. Hj. Ramlah / Aslan dari Tenggarong (Nur Sehan, Wahidah, Mahmudi, Muzakki, Yamani, Haetami). (Dokumen Kantor SMP Al Azahar Mandiri September 2015)

\section{Riwayat Pendidikan Formal Dan Non Formal}

Rustam Arsyad masuk Volk School (SD) Kelas III berijasah 1931, masuk Voor Volk Schoo 1Kelas V 1933, Madrasah Ibtidaiyah Alkhairaat 1933, Pesantren Alkairaat Lanjutan Pertama Berijasah 1936, Pesantren Alkairaat Lanjutan Atas Berijasah 1939, Pesantren Alkairaat Tingkat Tinggi Berijasah 1954

\section{Perkawinan Rustam Arsyad}

Kemudian Rustam Arsyad kawin dengan Rachmah dg Mennessa binH. Latangnga bin Petta Janggo dari Sengkan, memiliki 7 orang anak yaitu :Zakinah, $\mathrm{Hj}$. Subaedah Arsyad / pekerjaan rumah tangga, Abdullah Basyid Arsyad/ Dosen STAIN, Hasbullah Arsyad / guru, Taufid Arsyad / Wiraswasta dan Muslimin Arsyad / wiraswata danMunifah Arsyad / wiraswasta.Beliau menjadiuswahkhasanah dan pelita keluarga khususnya dan umat Islam pada umumnya. Rustam Arsyad banyak potensi yang dimiliki sehingga ia dikenal sebagai seorang guru, ulama, politisi dan da'i. Potensi ulama, guru dan da'i paling menonjol selama karirnya. Beliau tidak hanya dikenal sebagai Ulama Ahli Fiqhi, da'i senior di kotaPalu tetapi juga sering mengangkat tema fiqh, baik hukum Islam tradisional maupun yang aktual di diskusikan di masyarakat.

Beliau aktif berdakwah yang mempertemukan antara dirinya dengan masyarakat luas kapan dan dimana saja. Ceramah pada umumnya disampaikan dengan bahasa Kaili (bahasa daerah Palu), bahasa Bugis, dan bahasa Banjar, dakwah seperti ini sangat tepat karena sesuai dengan tuntunan Nabi Muhammad Saw, berkomunikasi dengan masyarakat sesuai tingkat daya kemampuan mereka. Oleh karena itu memberikan dakwah harus dikedepankan rasa simpatih, cinta dan kekaguman terhadap masyarakat dan fatwa moderat yang bisa menyejukkan hati. Beliau Secara pshikologis, pendekatan dakwah seperti ini sangat tepat karena sesuai dengan tuntunan Nabi Muhammad Saw, berkomunikasilah dengan manusia sesuai tingkat daya kemampuan mereka. Oleh karenaitu Rustam Arsyad berhasilmembangkitkan rasa simpati, cinta dan kekaguman masyarakat kepada dirinya, dicintai, rindu, dan selalu ditunggu fatwa moderat yang menyejukkan hati.

Rustam Arsyad, murid angkatan pertama Al-Habib Sayid Idrus bin Salim Aljufri atau Guru Tua (1891-1969) pendiri Pesantren Alkhairaat Palu Sulawesi Tengah. Rustan Arsyad dengan beberapa teman seangkatannya disebut oleh Guru Tua sebagai murid utama (generasi perintis pesantren Alkhairaat). Disebut murid utama oleh ulama kharismatik. Keseharian Rustan dikenal sangat disiplin dalam membangun ekonomi keluarga hanya bertumpu pada usaha menjahit, tetap kelihatan sederhana, baik dalam penampilan maupun pergaulan sehari-hari dengan berbagai lapisan masyarakat.

Dalam pemikiran Rustam Arsyad, selalu haus dengan ilmu dan pengalaman, karena itu sekitar 1948 dia magam di Madrasah Normal Islam School Amuntai Kalimantan Selatan yang dipimpin oleh K.H.Idham Khalid (mantan Ketua Umum PBNU dan MPR RI). Di sana Idham diminta mengajar sambil belajar administrasi pendidikan modern. Ketika dia kembali ke Palu, ia membuka madrasah muallimin Alkhairaat pada 1959 dan beliau ditunjuk oleh Guru Tua untuk memimpin Madrasah tersebut. Berdirinya Madrasah muallimin Alkhairaat 1968 dan Rustam Arsyad sebagai kepala sekolah pertama dan sebagai periode baru berdirinya sejarah 
pendidikan modern di perguruan Alkhairaat Kota Palu. Kemudian pada 1971 Madrasah Muallimin berubah menjadi Madrasah Aliyah Alkhairaat (MAA) dengan memakai kurikulum Departemen Agama RI. Rustam Arsyad tidak pernah melewatkan waktunya untuk membaca kitab gundul di depan Guru Tua, baik pada saat menjadi santri maupun pada saat menjadi kepala Madrasah. Dalam waktu singkat, ia populer sebagai ulama dan da'I muda dalam pembinaan umat Islam di Sulawesi Tengah, terutama di bidang akhlak dan penyebaran pemikiran fikih moderat khususnya mazhab Syafi'i. Rustam Arsyad sebagai juru bicara Guru Tua dalam bidan ghukum Islam. (Abd. Gani Jumat).

Rustam Arsyad pertama masuk sekolah di Madrasah Muallimin Alkhairaat pada 1933 selama 4 tahun yang dibimbing oleh Guru Tua,dengan keberhasilan bimbingan guru tua, Rustan Arsyad menjadi santri yang cerdas, disiplin dan mandiri, pada 1937 ia diangkat sebagai guru bantu pertama untuk mengajar di madrasah Alkhairaat di sore hari oleh Guru Tua. Pada periode 1941-1945 dia diangkat sebagai Kepala madrasah Ibtidaiyah Alkhairaat dan menjadi Kepala madrasah Muallimin Alkhairaat pada periode 1959-1968. (Ibid)

Rustam Arsyad, adalah murid angkatan pertama Al-Habib Sayyid Idrus bin Salim Aljufriatau Guru Tua (18911969) pendiriPesantrenAlkhairaatKota Palu. Rustan Arsyad dengan beberapa teman seangkatan disebut oleh Guru Tua sebagai murid utama (generasi perintis pesantren Alkhairaat) ulama Kharismatik. Rustam dikenal sangat disiplin dalam membangun ekonomi keluarga dengan penghasilan hanya mengharap pada hasil usaha menjahit, sangat sederhana, baik dalam penampilan maupun pada pergaulan sehari-hari dengan berbagai lapisan masyarakat. Sebagai murid utama Guru Tua, Rustam Arsyad sangat dipengaruhi oleh visi Gurunya, menjelaskan bahwa untuk merubah dan membina moralitas masyarakat Palu dan sekitarnya, harus dimulai dari Madrasah, sehingga peranan seorang guru menjadi sangat penting. (Abd. Gani Jumat).

Rustam Arsyad mendirikan Madrasyah Diniah Awaliyah, sebagai tempat pengajian dasar, pada awal tahun 1985 lembaga pendidikan ini adalah sebuah taman pengajian yang dimulai dari 12 orang murid anak tetangga yang belajar membaca Al-Qur'an diteras rumah peribadi ketua Majelis Ulama Indonesia (MUI) KH Rustan Arsyad, sebagai anggota DPRD Sulteng dan mantan MPR RI. langsung belajar penyebutan hurup tajewid yang diajarkan oleh Hj. Rachmah dg Manessa. Di sekolah ini 1 keluarga terlibatmengajar anak mengaji. Rustan Arsyad mengajar mahfudzat, Abdul Basyid mengajar Imlat, Ibu Rachmah mengajar Tajewid dan Subaeda mengajar Tamsilulkulub. Sehingga dari awal anak terkesan cara penyebutan huruf Al-Qur'an, ini atas petunjuk Ustas Rustan Arsyad.

Kegiatan dan Aktivitas dalam Membina dan Mendidik Masyarakat.Pada periode 1947-1965 Rustam Arsyad menjadi ketua Partai Syarikat Islam Indonesia (PSSI) M.O.D. Syariah Wal Ibadah, menjadi Wakil Ketua K.M.I (Kepanduan Muslimin Indonesia) 1948, ketua Umum PB. Alkhairaat (Muktamar I) di Palu 1955, ketua Umum PB. Alkhairaat (Muktamar II) di Ampana 1976, ketua GUPPI Prop. Sulteng pada tahun 1970 (Seksi Da'wah dan Keulamaan), Ketua Majlis Da'wah Islamiyah (MDI) Kab. Donggala 1978, Ketua DPD GolkarTk I Sulawesi Tengah 1978-1984, Wakil Ketua Dewan Ulama Alkhairaat, Anggota Dewan Pertimbangan Golkar Sulteng, Anggota Dewan Penyantun Universitas Tadulako Palu 1970-1985 dan Ketua Umum Majelis Ulama Sulawesi Tengah pada periode 1986-1991.

Karya tulis yang ditinggalkan berupa buku atau brosur tidak ada. Rekaman pidato atau ceramah tidak ada tapi Rustan Arsyad mendirikanlembaga pendidikan Madrasyah Ibtidaiyyah yang diawali dengan pengajian anak anak sebanyak 10 orang diteras rumah beliau, kemudian Madrasyah ini dikembangkan oleh H. Abd. Basyid anak ke 
2 beliau menjadi SMP dan SMA Al-Azhar Mandiri di kota Palu sejak 2011sampai sekarang 2015 siswa berprestasi Internasional dan Nasional.

Abd. Basyid Rustan kepala sekolah SMP dan SMA Al-Azhar Mandiri tak pernah membayangkan kalau sekolah yang dirintisnya 23 tahun yang lalu kini menjelma menjadi sekolah favorit di daerah ini. Sebutan favorit datang dari masyarakat, tertama orang tua siswa yang berlombalomba ingin menyekolahkkan anaknya di sekolah menengah pertama SMP yang beralamat dijalan tanjung Malakosa Palu Selatan dan SMA Al-Azhar Mandiri di Jalan Garuda Palu. Kami tak ingin disebut favorit, karena masih banak kekurangan. Bisrakan masyarakat saja yang menilainya seperti itu, kata Abd Basyid, mantan Sekjen Himpunan Pemuda Alkhaerat (HPA).

Ustas Abdul Basyid Rustan Arsyad mengatakan setiap tahun orang tua siswa datang dari berbagai daerah di Sulawesi Tengah untuk menyekolahkan anaknya di SMP Al-Azhar. Untuk itu kami melakukan seleksi ketat. Hanya siswa yang mampu memenuhi standar nilai bisa masuk. Dia mengatakan modal dasar Al-Azhar adalah adil dan jujur karena itu dirinya tak goyah dengan bujukan apalagi rayuan orang tua yang ingin meloloskan anaknya di sekolah SMP/SMA berapapun yang dia bayar. Sekali saja kita menerima sogokan, maka kehancuran diambang pintu karena itu adil dan jujur merupakan kata kunci. Meski ini pahit bila berhadapan dengan keluarga, teman karib dan lainnya, kata Ustas Abdul Basyid.Maka berlomba-lombanya orang tua siswa menyekolakan anaknyake SMP/SMA Al-Azhar, cukup beralasan. Berbagai prestasi yang pernah diukir oleh para siswa di bidang akademik maupun bakat. Prestasi bukan hanya ditingkat lokal, namun pada ajang nasional. Ratusan piala dan Piagam menjadi bukti. Lemari kaca diruang kepala sekolah nyaris tak mampu lagi menampung berbagai piala. Fasilitas penunjang sarana belajar, seperti laboratorium komputer, IPA, Perpustakan, kesenian, Olahraga dan kesiswaan tersedia.
Ruang kepala sekolah, guru, dan ruang kegiatan belajar tertata dengan rapi.

Kami tegatkan disiplin. Saat jam pelajaran berlangsung siswa dan guru tidak boleh ada keluyuran. Boleh dicek diluar itu sepi, karena belajar semua, kata Abdul Basyid yang perna menjadi kepala sekolah SD Indonesia di Damaskus selama empat tahun. Dalam setiap ajang perlombaan dibidang akademik, SMP Al-Azhar menjadi baik ditingkat provingsi, nasional apalagi ditingkat kota Palu. Al-Azhar sudah kenyang dengan prestasi seperti Olimpiade sain nasional (OSN) selalu juara umum. Begitu juga Olimpiade Olahraga nasional (O2SN) status juara umum menjadi langgganan. Sosial prestasi tak hanya diraih siswa, guru bidang studi matematika dan biologi di sekolah standar nasional (SSN) tersebut juga mengenyam pelatihan hingga ke Australia. Guna terus menjaga mutu, siswa berprestasi masuk kedalam kelas unggulan dengan sistem belajar dari pagi hingga sore. Kegiatan extrakurikuler dilaksanakan selama seminggu penuh setelah pulang dari sekolah. Semua prestasi itu kata ustas Abd Basyit tak lepas dari semangat dari spirit Guru Tua. Ia menilai apa yang di capai SMP dan SMA Al-Azhar merupakan manifestasi dari ajaran Guru Tua kepada Ayahandanya KH Rustan Arsyad yang merupakan murid kesayangan Guru Tua.

Rustan Arsyad mantan ketua Golkar Sulteng dan menjadi kepala sekolah Muallimin alkhaeraat terlama (13 tahun) di anggap sebagai murid yang tercerdas oleh Guru Tua. Ditangannya Ulama Al-Khaeraat lahir. Ajaran Guru Tua soal keterbukaan, disiplin, dan menyayangi semua kelompok. diterapkan di SMP dan SMA Al-Azhar mulai dari anak hingga anak pejabat penting di Sulawesi Tengah. Selain itu murid murid non Muslim juga diterima di SMP dan SMA Al-Azhar. (Media Al-Khaeraat Adventorial. 2015:. 21)

\section{Sejarah Berkembangnya SMP Al-Azhar kota Palu}


Pada awal mulanya ide pendirian SMP Al-Azhar Palu dimulai dari seorang anak muda Abdul Basit Arsyad yang memimpikan membangunan suatu sekolah swasta yang suatu saat nanti akan mejadi sekolah unggulan dan disegani di Sulawesi Tengah. Pada awal Mei tahun 1992 didirikanlah sekolah tingkat lanjutan pertama atau di sebut SLTP Al-Azhar, setelah mendapat persetujuan dari pihak pemerintah yakni Kanwil Depdikbud Propinsi Sulteng tertanggal 7 Mei 1992. $\begin{array}{lll}\text { Sehinggasetiaptanggal } & 7 & \text { Mei }\end{array}$ ditetapkansebagaiharilahir SMP Al-Azhar Palu. Pada awal pembukaannya, siswa yang mendaftar sekitar 40 org, dibawah binaan 7 orang guru. Diantaranya Drs Abdul Basit Arsyad sebagai kepala sekolah, Dra Zahrah Hi Latanga sebagai wakil kepala sekolah, Dra Ahmad Arifuddin sebagai guru merangkapkepala tata usaha.Umumnya siswa yang masuk pertama adalah siswa yang tidak diterima disekolah negeri dan bisa dikatakan sebagai siswa buangan yang berasal dari keluarga ekonomi menengah kebawah seperti anak-anak kusir dokar, buruh bangunan, penjual ikan di pasar dlsb. Dan setelah proses belajar mengajar berjalan selama tiga tahun hingga akhir satu periode pengajaran, siswa yang lulus ujian akhir nasional pada angkatan pertama yaitu tahun 1995 adalah 24 org (Pendaftar 40 orang). Hal inidisebabkan oleh ketatnyapenegakanaturan dan disiplinsekolah.

Diawa lpriode dan kedua, yaitu pada tahun 1995 dan 1996, selama dua tahun SLTP Al-Azhar belum dapat melaksanakan sendiri ujian akhir nasional. Dan harusmengikutiujiannasional di sekolahlain, yaitu pada SLTPN 1 Palu Jl Gatot Subroto. Tahun 1997 terbitlah SK Kakanwil Depdikbud Provinsi Sulteng dan menetapkan SLTP Al-Azhar PalusebagaisekolahpenyelenggaraUjian

Nasional sehingga dapat melaksanakan sendiri ujian akhir nasional dan diikuti sebanyak 59 orang siswa, dengan angka kelulusan 100 persen. Lembaga swasta ini mendapat akreditasi pada tanggal 6 Mei
1996 dengan status "Diakui" oleh Dirjen Pendidikan Dasar dan menengah.Pada bulan Januari tahun 2001 pendiri dan kepala sekolah pertama SMP Al-Azhar Palu Drs Abdul Basit Arsyad diangkat oleh Mendiknas sebagai kepala sekolah Indonesia di Kedutaan Besar RI Damaskus Suriah dari tahun 2001 s/d 2004 dan kepala SLTP Al-Azhar pengganti dijabat oleh Drs Ahmad Arifuddin sampai akhir Desember 2004. Selanjutnya mulai tanggal 5 Januari 2005 Drs Abdul Basit Arsyad kembali menjabat sebagai kepsek SMP Al-Azhar Palu hingga sampai sekarang.

Pada tahun 2007 SMP Al-Azhar Palu mendapat status "Terakreditasi A" oleh Depdiknas. Dan tahun 2008 mendapat status SSN (Sekolah Standar Nasional) dan kemudian bulan Agustus tahun 2009 SMP Al-Azhar Palu ditetapkan oleh Direktur SMP Depdiknas sebagai RSBI atau Sekolah Rintisan Bertaraf Internasional. Pada awalnya lokasi lembaga pendidikan ini berdiri diatas lahan yang berukuran kurang lebih 4000m3, namun setelah berkembang beberapa tahun kemudian, lahan tersebut bertambah menjadi kurang lebih 9000m3. Kini (Agustus 2010) SMP Al-Azhar Palu memiliki 500 siswa, 40 guru dan 1500 alumni. (Dokumen SMP AlAzhar Mandiri kota Palu).

Rustam Arsyad sangat di akui pada saat itu dalam memberikan cerama biasa saja tapi kaya'nya ada mahnik menarik, topik ceramanya selalu dalam masalah hukum kecuali pada peringatan Isra' Mi'raj, dia menekankan pada paham Syafii, membahas tentang tasawuf maka banyak merujuk pada Ihya ulumuddin Al Gazali. Ada pernyataan guru tua terhadap seluruh murid, bahwa semua murid masuk kanton bila berbicara dalam soal piqhi kecuali ustas Rustam Arsyad, yang bisa keluar hanya ustas Rustam Arsyad, artinya hanya Rustan Arsyad bisa menyelesaikan masalah piqhi, jadi berbicara dalam masalah hukum hanya ustas Rustan Arsyad yang bisa menjawab. Memang pada masa hidup guru tua, ada masalah hukum muncul, maka diarahkan 
untuk menyelesaikannya adalah Rustan Arsyad.

Kembali dari Banjar masing 1940 kemudian ia mendirikan Muallimin di AlKhaerat dengan mengharapkan Gurru Tua memberikan Tema pengajian kepada masyarakat yang belajar "Khalaqa Qiraah" dikembangkan oleh putra Abdul Basyid Arsyad mmenjadi Yayasan Al-Azhar Mandiri di kota Palu. Rustam Arsyad sebagai tokoh ulama Al-Khaerat. Beliau pendiri Madrasyah Ibtidaiyyah, kemudian ketika Rustam Arsyad meninggal maka Madrasyah Ibtidaiyyah dikembangkan oleh Abdul Basyid anak ke 2 dari 6 bersaudara satu Ibu, beliau menjadi kepala Yayasan AlAshar Mandiri kota Palu. Rustan Arsyad mengajar di Madrasyah Ibtidaiyah, Aliyah dan perguruan tinggi Fakultas Syariah selama 20 tahun, pengajian ceramah agama dan berdakwah pada semua organisasi.

\section{Sikap dan PandanganKeagamaan yang berpengaruhdalam Masyarakat}

Kehidupan keluarga melayani segala kebutuhan keluarga sesuai kemmampuan, terkait dengan Jodoh tidak terikat, $\mathrm{KH}$. Rustam Arsyad pertama kawin dengan orang Banjar, anaknya bernama Zakinah. Kedua, kawin dengan $\mathrm{Hj}$. Wariyah orang Kaili tidak ada anak. Dan ketiga, ia kawin dengan Rachmmah dg Mennessa bin petta Janggo, orang Bugis turunan dari Sengkkang memiliki 7 anak. Istri bekerja sebagai guru mengaji. Pendidikan anak, memilih sekolah sendiri, perbedaan sekolah dan madrasah memilih sesuai bakat anak. Pendidikan masyarakat adalah Pengajian di masjid selesai cerama di buka tanya jawab, melayani pertanyaan masyarakat, bimbingan kepada para ustadz.

Kealiman Rustam Arsyad Ulama adalah warisan para Nabi dan menguasai ilmu; Ilmu qiraat, Asbabun nuzul, nasihk dan mansuhk, menguasai ilmu hadits dan banyak hapal hadits, ahli dalam aqidah Islam secara luas dan mendalam, baik dari segi Filsafat, logika, dalil aqli dan dan dalil naqlinya. Menguasai pemahaman, penghayatan dan pengamalan akhlaq lahir dan bathin serta metodologi pencapaiannya. Memahami Hukum Islam menguasai dalildalilnya metode penyimpulan dari AlQur'an dan Hadits, mengerti pendapat para ahli dan ahli pada berbagai bidang yang diperlukan sebagai sarana pembantu untuk dapat memahami al-qur'an dan Hadits, seperti ahli bahasa, ahli mantik dan ahli sejarah.

Pada tradisi Islam, ulama diberi kepercayaan untuk merawat pengetahuan keagamaan, tadisi kesarjanaan muslim tidak hanya terkait dengan kepasitas intlektual, tetapi perilaku keseharian. Kealiman seseorang tidak hanya diukur dari kecerdasan intlektual, tetapi perilaku yang mencerminkan teladan yang baik. Sosok Rustam Arsyad yang sejak dari kecilnya sangat cinta gesit menuntut ilmu pengetahuan tanpa mengenal bats waktu, ruang dan guru telah membawahnya menjadi seorang alim ulama yang termasyhur. Kedalaman dan keluasan Ilmunya tidak mampu terukur dari para peserta didiknya. Penguasaan Ilmunya sangat utuh dan kompleks menembus batasbatas kategorisasi keilmuan ulama.

Muchith Muzadi, mengemukakan bahwa semua kategori ilmu tersebut dimiliki dan dikuasainya secara kompeten dan diajarkannya secara professional. Kedalaman dan keluasan kompetensi keilmuan Rustan Arsyad tersebut tidak terlepas, oleh karena beliau adalah orang yang tekun dan unlimited dalam menuntut ilmu dan disertai dengan dukungan kecerdasan nalar Intlektual, Spiritual, Emosional, dan Sosialnya. Ke 'aliman dan keulamaan Rustan Arsyad sangat diakui oleh para peserta didiknya dan ulama sezamannya, bahkan sampai saat ini. Khuzaimah Tahido Yanggo, yang dikutip oleh Achmad Bachmid dalam bukunya "Sang Bintang dari Timur" mengemukakan bahwa "Rustan Arsyad adalah orang yang ganius, sangat ahli, all round, dan serba bisa. Rustan Arsyad benar-benar seorang ulama, sejarawan, penyair, pendidik, da'i, dan Interpreneur". Rustan Arsyad adalah otodidak yang berhasil. Kedalaman dan 
keluasan ilmu yang dimiliki Rustan Arsyad bukan hanya diakui oleh kalangan Alkhaeraat dan umat nusantara.

Rustam Arsyad adalah figur masyarakat Sulteng yang memiliki 7 putra putri. Masyarakat mengenal beliau sebagai seorang Ulama/Muballig senior, ahli dibidang piqhi dan politisi. Pada saat beliau duduk sebagai ketua Majelis Ulama Indonesia (MUI) Sulteng. Sering mengangkat masalah dalam ceramahnya Fiqhi dan hukum Islam. Beliau mantan anggota MPR dan mantan ketua MDI Sulteng. Baliau sebagai salah seorang tokoh PB Al-Khaerat selama 15 tahun sejak terbentuknya pengurus besar Al-Khaerat, beliau termasuk murid terbaik dari KH. Sis Al-Jufri yang lebih dikenal dengan Ustas guru Tua.Beliau memiliki kerja sampingan sebagai tukan jahit untuk menghidupi keluarga. Nanti pada 1985 ia melepaskan propesi tersebut karena banyak kesibukan dari jabatan yang dipercayakan sebagai anggota DPRD Tkt I Sulteng Fraksi Karya Pembangunan.Beliau dikenal kesederhanaannya dalam masyarakat golongan kecilpun senang mendekati beliau karena ia lebih senang memperhatikan masyarakat kaum lemah. Beliau keturunan Banjar, masyarakat menganggapnya beliau sebagai putra kaili dan dia sendiri mengakui dirinya asli Palu.

Rustam Arsyad pendiri Madrasyah Diniah Awaliah, sebagai tempat pengajian dasar dan tajewid yang memakai kurikulum bahsa Arab, yang diajar oleh Rachmah dg Manessa Isteri Rustan Arsyad, KH. Rustan Arsyad, Abdul Basyi dan Subaeda. Anak anak mengaji langsung diterapkan bacaan tajwid, sehingga dari awal anak anak terkesan cara penyebutan huruf Al-Qur'an, ini petunjuk Rustan Arsyad karena memang beliau ahli fiqhi dan usul. Kemudian dikembangkan oleh anaknya Abd. Basyid M.Pd menjadi SMP dan SMA Al-Azhar Mandiri di kota Palu. Beliau sangat di akui pada masanya. Beliau tidak orator berapi api mengungkapkan segalanya, tapi biasa saja mengungkapkan suatu masalah namun terasa ada tarikan husus, cerita biasa saja diulas tapi masyarakat sangat antusias mendengarnya dibanding muballig muballig yang berorator masyarakat mendengarnya 2-3 $\quad$ m mereka menganggapnya suda biasa. Banyak muballig yang oratornya manarik tapi bila suda berulang mereka bilang saya dengar. Cerama beliau biasa saja tapi kaya'nya ada mahnik dari topik ceramanya selalu dalam masalah hukum kecuali pada peringatan Isra' Mi'raj, selalu menekankan pada paham Syafii, bila membahas tentang tasawuf maka banyak merujuk pada Ihya ulumuddin, dan Al Gazali.

Rustam Arsyad bisa menyelesaikan masalah piqhi, jadi berbicara dalam masalah hukum hanya ustas Rustan Arsyad yang bisa menjawab,ada masallah hukum muncul, maka diarahkan untuk menyelesaikannya adalah Rustan Arsyad. Dalam masalah administrasi dia perna belajar sama H. Idham Halik, pernah menjadi magam di sekolah binaan Idham Halik di Banjar Masing. Rustam Arsyad kawin pertamamemiliki satu anak bernama Zakinah, kawin kedua bernama $\mathrm{Hj}$. Wariah tidak memiliki anak dan pada ke 3 bernama $\mathrm{Hj}$. Rachmah Dg Manessa, seorang guru Madrasyat Ibtidaiyyah Al Azhar Mandiri (MI) guru mengaji / kiraah, memiliki 6 orang anak:

1. Hj. Subaedah Rustam/ pekerjaan rumah tangga, STAIN.

2. Abd. Basyid Rustam/ Dosen

3. Abdullah Rustam.,

4. Hasbullah Rustam / guru.,

5. Taufid Rustam / Wiraswasta.,

6. Muslimin Rustam / wiraswata dan

7. Munifah Rustam / wiraswasta.

KH Rustam Arsyad (sapaan masyarakat secara umum dan lebih khusus kota Palu). Kai (sapaan dalam lingkungan keluarga dan cucuhnya). Ustas Rustan/ Guru atau pak kiyai (sapaan murid atau siswa di Pesantren). Rustam Arsyad sebagai kepala sekolah Mu'alimin Al-Khaerat, ahli dibidang fiqhi Islam yang menekankan kedisiplinan dalam segala hal kegiatan. Diwaktu pagi dan sore ada waktuna dia 
pergi menjahit pakaian, berda'wah, mencari pakaian jahitan. (Dokumen Kantor SMP Al Azahar Mandiri September 2015)

Rustam Arsyad dilahirkan di Kota Palu, selagi masih kecilnya sudah nampak bakat dan kepemimpinan pada dirinya. Sifat kepemimpinan itu tergambar dalam tingkah lakunya, terutama dalam pergaulannya. Dalam pergaulan beliau tidak nampak membedakan orang yang menjadi temannya. Kepada orang yang lebih tua atau kedudukannya terhormat, diberikannya penghormatan dan penghargaan, sedangkan bagi yang sebayanya ditunjukkannya sifat pengayom. De $\neg$ ngan ini akhirnya semua orang merasa simpatik dan terjelmah hubungan akrab dari orang tersebut dengan Rustam Arsyad.

Dari sifat yang dekat dan simpatik yang selalu ditunjukkan itu ke beberapa temannya yang seperguruan seperti Abdul Karim bin Salim bin Hamid, Ali bin Maharim Muhammad bin Sagaf bin Alwy Aldjulri, memuji atas keperibadian Rustan Arsyad selama dalam pergaulan pendidikan mereka dalam lingkungan. Sebagai seorang cendekiawan muda yang banyakbelajar tentang keagamaan, beliau tergolong ulama muda yang moderat, teguh dalam pendirian. Ini ditandai ada sesuatu yang harus dibicarakan atau diselesaikan, maka Rustam Arsyad tidak terlalu sulit untuk memuluskan dengan melalui, jalan kompromi dan musyawarah. Rustan Arsyad dikalangan masyarakat adalah seorang yang berpengaruh dan berwibawa. Kegiatan dalam masyarakat tidak diabaikan, inilah Dasar pemikiran Rustam Arsyad.

Dalam membangun dan mengembangkan Alkhairaat Rustam Arsyad memimpin menempuh berbagai macama). Menghargai pendapat, usaha dengan lebih dahulu menyapa orang. Misalnya ada pendapat dalam masyarakat tentang masalah Agama, beliau dengan senang hati menerima. Bukan hanya berpendapat. Misalnya ada bantuan tapi tidak mau disebutkan namanya, Rustam Arsyad menerimanya, tetapi selalu diusahakan untuk mengetahui dari siapa bantuan itu. b). Sifat menyantuni sesama manusia, Rustam Arsyad bersifat sangat ramah dan menyatu dengan mereka itu. Misalnya menampung para pelajar yang berasal dari luar Palu dengan jumlah banyak. Para pelajar ditampung diasuh, dan segala kebutuhan mereka dilayani oleh Rustam Arsyad dengan tidak membedakan anak siapa, kaya atau miskin, bagi beliau.

Rustam Arsyad berhasil membangun dan mengembangkan Alkhairaat sampai kepelosok pedesaan. Itulah sebabnya Rustam Arsyad dijadikan oleh mereka sebagai pemimpin, yang apa saja keinginan atau kebutuhan beliau akan dipatuhi setiap warga Alkhairaal. d). Sifat untuk menemui/mengunjungi teman seprofesinya atau dikalangan alim ulama telah menjadi kebiasaannya, sehingga beliau diketahui dan dikenal dika $\neg$ langan Alim Ulama terutama di Indonesia. e). Rustam Arsyad dalam kehidupannya tidak ego, tidak menang sendiri. Contohnya: "Rustam Arsyad setiap mengadakan perjalanan da'wah keliling beliau disertai dengan barang dagangannya, terutama tujuannya untuk mendapatkan keuntungan dalam hal membiayai Madrasah dan Pelajar selain untuk pendekatan dengan semua orang. Satu waktu saya disuruh oleh Guru Tua untuk menjual barang-barang tersebut. Karena banyaknya orang yang membeli barang tersebut, Guru Tua mengatakan penjualan dihentikan dahulu. Alasan Guru Tua, karena ada juga orang lain berjualan dan menghindari jangan ada orang yang diistimewakan barang jualsaya. (Kembay B. Sofyan, 1991: 25-28)

Pandangan dan Sikap Masyarakat Atas Kelebihan yang Tercermin Pada Diri UlamaRustam Arsyad sebagai Ulamakota Palu dan sekitarnya, masyarakat mengetahui dan mengenal atas pribadi Rustan Arsyad selama hidupnya terutama di daerah ini. Dari beberapa orang yang mengatakan. (Ibid., h. 60) Ki. Hi. Rustam Arsjad, murid tamatan ke II Alkhairaat Pusat Palu yang lama hidup selalu dekat dengan Guru Tua untuk menimbah ilmu untuk di aplikasikan kepada masyarakat. 
Rustam Arsyad pada saat mendidik santrinya menggunakan metode pendekatan secara manusiawi. Selain membaca, mengajar dan da'wah. Rustam Arsyad menggunakan waktu mengikuti kegiatan olah raga seperti nonton bola kaki, pacuan kuda dan kegiatan kesenian yang bernafaskan Islam seperti qasidah. Rustam Arsyad mengatakan, sebagai seorang pimpinan harus mengetahui bela diri seperti silat, gunanya supaya tidak seenaknya orang menakut-nakuti. Itulah sebabnya Rustam Arsyad juga memiliki ilmu bela diri.

Bersikap sebagai Pendidik.Rustam Arsyad sangat dekat dengan semua orang. Dalam pergaulannya dengan anak murid selalu nampak bersama bekerja, belajar, berolahragadan kesenian. Rustam Arsyad selalu menggunakan kesempatan bercerita terutama pada kejadian di zaman Nabi. Malalui ini Rustam Arsyad mulai mendidik terutama merubah watak anak yang bersifat ego, bisa berubah menjadi orang yang sifat sosialnya tinggi. Anak yang selalu menonjolkan dirinya dengan kenakalan yang diandalkan sebagai usaha mempengaruhi teman, menjadianak yang patuh dan setia terhadap janji dan tugas yang diberikan kepadanya.

Rustam Arsyad bersama dengan anak tidak pernah menunjukkan sifat marahnya, tetapi apabila ada kekeliruan dan kesalahan dari muridnya, hanya dengan sapaan kata ;"Tidak boleh lagi berbuat seperti tadi, karena itu tidak baik dan merugikan".Menghargaijasa orang, menjadi pola perhatian Rustam Arsyad. Orang yang pernah membantu beliau, dalam keadaan apapun nama orang tersebutmenjadisebutandalampembicaraan nya. Tidakhanyademikian, apabila Rustam Arsyad menyuruh orang, selalu diberinya imbalan, sebagai tanda menghargai jasa orang yang bekerja membantunya.

\section{Manusia Belajar sepanjang Hayat}

Manusia suka belajar, maka tidak ada kata berhenti untuk belajar dalam hidup ini, karena hidup dan kehidupan terus berjalan, bahkan dalam Islam sendiri ada sebuah tuntunan yang disampaikan oleh Rasulullah saw."Menuntut Ilmu wajib atas tiap muslim laki-laki maupun perempuan (HR.Ibnu Majah). Tuntutlah ilmu mulai dari ayunan sampai kalian lahad. (Arif, M. Arifuddin, 2013:13).

Dalam pandangan Islam, belajar secara umum pendidikan, merupakan bagian yang diwajibkan bagi setiap muslim, baik pria maupun wanita. Pendidikan juga berlangsung seumur hidup, tidak mengenal batas usia. Kedudukan tersebut menempatkan pendidikan sebagai bagian yang tidak dapat dipisahkan dari kehidupan manusia. Al-Qur'an yang merupakan sumber ajaran pertama dalam Islam mengajarkan pentingnya belajar, hal ini terbukti dengan ayat pertama yang diterima Rasulullah saw. yang berbunyi Iqra (bacalah). Secara tersirat Allah swt memerintahkan manusia untuk belajar. Di dalam suatu hadits yang lain, Nabi bersabda:

"Tuntutlah kalian ilmu pengetahuan, sesungguhnya menuntut ilmu adalah pendekatan diri kepada Allah azza wajallah, dan mengajarkannya kepada orang yang tidak mengetahuinya adalah sedaqah. Sesungguhnya ilmu itu menempatkan pemiliknya pada kedudukan tinggi lagi mulia. Ilmu adalah keindahan bagi ahlinya di Dunia dan Akhirat.

\section{Sifat Teladan Dalam Kehidupan Rustam Arsyad}

Rustam Arsyad, banyak mengalami pasang surut, romantika kehidupan, terutama dalam pembinaan kelanjutan Alkhairaat. Ada beberapa kesan yang bisa diteladani, terutama dalam menghadapi kehidupan yang serba aneka ragam ini. Dan menghindari hambatan dan bisa menjadi sukses usaha tersebut perlu dilandasi keikhlasan hati dan bertaqwa. Sifat patuh kepada Allah swt.Kepatuhan yang dimiliki oleh Rustam Arsyad adalah patuh dalam menjalankan perintah Allah SWT. Dengan bimbingannyalah, sehingga segala sesuatunya terlaksana dengan baik. Rustam 
Arsyad berusaha mengikuti petunjuk ilham. Semua hal ini atas karunia dari Allah SWT. Itulah sebabnya beliau tidak hentinya menyampaikan kesyukurannya kepada Tuhan Maha Besar atas kehendaknya itu.

Satu kata dengan perbuatan. Selama Rustan Arsyad dalam pergaulannya dengan masyarakat dari tingkat atas sampai kepada rakyat biasa, beliau selalu menunjukan sikap yang merakyat. Artinya dapat memahami keinginan orang banyak itu. Apabila Rustam Arsyad memberikan petunjuknya, diusahakannya ditepatinya. Dari tingkah laku yang dikatakan "satu kata denganperbuatan" adalah yang menjadi kebiasaan bagi beliau. Itulah sebabnya Rustam Arsyad selalu menjadi kenangan setiap orang. Teguh Pendirian dan berani. Sifat teguh pendirian, kuat keyakinan dan percaya pada diri sendiri adalah prinsip yang dianut Rustam Arsyad. Pengaruh dan bujukan untuk merubah pendirian tidak menggoyahkan. Ancaman tekanan yang diberikan untuk dapat merubah pendirian tidak menurunkan semangat dalam perjuangannya terutama dalam menegakkan yang benar. Mengagumkan Ilmu Pengetahuan. Banyak orang mengatakan selama hidup Rustam Arsyad menghabiskan waktu hanya untuk belajar, bekerja dan beribadah yang banyak melalui muridnya yang biasa menyertai apabila Rustam Arsyad berkunjung ke Lembaga Alkhairaat. Selama dalam perjalanan kegiatan digunakan waktu untuk belajar mengajar kepada siapa saja yang berada di sekitarnya, waktu, tersebut, dan keadaan tidak menjadi terikat baginya. (Dokumen SMP Al-Azhar Mandiri Media Surya, Sabtu 6 April 1991).

\section{PENUTUP}

Ketika Rustan Arsyad selesai pendidikan formal dan non Formal pada tahun 1939 dia diberi pengakuan keilmuan dan Ulama besar dari Ulama Guru besar Sayyid Idrus bin Salim Al-Jufri 1954, KH. Idham khalid mantan ketua PB NU, mantan ketua MPR RI. Dan mantan Menteri Agama RI. Keberadaan Rustan Arsyad sebagai seorang ulama besar, ahli Piqhi, Hukum Islam dan Politisi, guru Al-khaerat, ketua Umum PB Al-Khaeraat selama 2 periode, ketua Mutamar I dan II 1955-1963. Kepala Madrasah Muallimin Al-Khaerat 3 thn (SGA) kotaPalu 1955-1968, Hakim Mahkamah Syariah Pengadilan Agama Donggala 1965-1988.Anggota MPR RI utusan Daerah Sulawesi Tengah 1981-1982 dan Anggota DPRD Tk. I Sulteng 19851991. Melakukan pengajian khalaqah dibeberapa Masjid yang di ikuti dengan tanya jawab. Ia terlibat sebagai unsur pimpinan diberbagai Organisasi Sosial dan keagamaan.

Hasil penelitian ini diharapkan bermanfaat bagi jajaran Kementerian Agama dan instansi lainnya yang berkepentingan sebagai data keagamaan yang dapat dijadikan dasar pertimbangan dalam pengambilan kebijakan pembangunan di bidang agama. Para akademisi, pecinta ilmu, serta pihak-pihak lainnya sebagai informasi faktual untuk kepentingan pengembangan pengetahuan. Kepustakaan masyarakat sebagai pengayaan khazanah keagamaan yang dapat berguna sebagai acuan moral dan intelektual.

\section{UCAPAN TERIMA KASIH}

Penulis mengucapkan terima kasih kepada Kepala Balai Litbang Agama Makassar yang telah memberikan waktu penulis untuk melakukan penelitian ini. Kepada Kepala SMP Dan SMA Mandiri kota Palu beserta Staf atas kesediannya menerima peneliti melaksanakan penelitian. Dengan ucapan terima kasih kepada Tim Redaksi Jurnal Educandum atas publikasi hasil penelitian ini. Ucapan terima kasih kepada Informan dan semua pihak yang telah memberikan masukan atas penelitian ini.

\section{DAFTAR PUSTAKA}

Azyurnardi Azra, "Biografi sosialIntelektual ulama perempuan pemberdayaan historiografi" dalam 
Jajat Sumarja (ed.), Ulama Perempuan Indonesia. Jakarta; Gramedia Pustaka Utama, 2002).

Abdullah, Taufik (ed) 1983. Agama dan Perubahan Sosial. Cet. I. Jakarta: CV. Rajawali bekerja dengan yayasan Ilmu-Ilmu Sosial (YJIS).

Ahmad, Abd. Kair. 2008. Ulama Bugis. Cetakan I. Makassar: Indobis. Diterbitkan untuk Bala iPenelitian dan Pengembangan Agama Makassar.

As'ad, Muhammad dkk 2011. Buah Pena Sang Ulama. Jakarta: Indobis,

Arif, M. Arifuddin, 2013, The Spirit Of Leaning, Pn. Kerjasama EndeCe, Ct. I. 2012, Sayyid Idrus bin Salim Aljufri, Guru Tua: Pendidik dan Pembelajar Unggul,Cet. I, Pn. Endece Press,

Burhanuddin, Jajat (ed).

Ulama Perempuan Indonesia. Jakarta: GramediaPustakaUtama, 2002.

BPS Kota Palu Dalam Angka 2014

Farid Ahmad, Syaikh. 2012, Biografi 60 Ulama Ahlusunnah yang paling berpengaruh dan Fenomenal Dalam Sejarah Islam, Pn. Darul Haq, Ct. I,

Glasse, CyriI, Ensikiopedi Islam (Ringkas). Cetakan Ketiga. Jakarta: PT.RajaGrafindoPersada.

Gani Jumat, Abdul, Sang "Baku uratul" Khaeraat K.H. Rustam Arsyad (1922 - 1991)

Dosen Al-Khaerat dan IAIN kota Palu, 2 oktober 2015

Horikoshi, Hiroko. 1987. Kyai dan perubahan Sosial. Cetakan Pertama, Jakarta: P3M.

Jurnal Al-Qalam, 2013, Penelitian Agama Filosofi dan Sistem, ISSN 0854 1221, volume 19 Nomor 1.

Kembay B. Sofyan, 1991, Perguruan Islam Al Khaeraat dari Masa kemasa.

Ruslan, Muhammad dan Waspada Santing. 2007. Ulama Sulawesi Slatan: Biografi Pendidikan dan Dakwah. Makassar: Komisi Informasi dan Komunikasi MUl Sulsel.
Sugiyono. 2010, Metode Penelitian Pendidikan pendekatan Kuantitatif, Kualitatif dan R\&D, Pn. Alfabeta, Bandung, Cet. Ke 9

Santing,Waspada. 2010, Ulama Perintis Biografi Mini Ulama Sulsel, Makassar Al-Zikra,.

Syamsuddin, Helius. 2007. Metodologi Sejarah. Yogyakarta:

PenerbitOmbak.

Suprapto, Bibit. Ensikiopedi Ulama Nusantara Riwayat Hidup, Karya dan Sejarãh Perjuangan 157 Ulama Nusantara.

Turmudi, $\quad$ Endang. 2004. PerselingkuhanKiai dan kekuasaan. Cetakan I. Yogyakarta:

LkiS.

wawancara H. Abd. Basyid M. Pd 30 Sep 2015 di SMP Al Azhar Mandiri kota Palu.

Wawancara KH. Mansur Baba, 3 Oktober. 2015

Dokumen Kantor SMP Al Azahar Mandiri September 2015 